\title{
Evaluating the Effects of MKAVCFSL Derived from Bighead Carp (Hypophthalmichthys nobilis) Flesh on Antioxidant Activity in Caco-2 Cells In Vitro
}

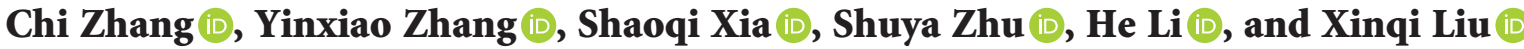 \\ Beijing Advanced Innovation Center for Food Nutrition and Human Health, Beijing Engineering and Technology \\ Research Center of Food Additives, National Soybean Processing Industry Technology Innovation Center, \\ School of Food and Health, Beijing Technology and Business University, Beijing 100048, China \\ Correspondence should be addressed to Xinqi Liu; liuxinqi@btbu.edu.cn
}

Received 31 March 2021; Accepted 23 April 2021; Published 4 May 2021

Academic Editor: Shengbao Cai

Copyright (c) 2021 Chi Zhang et al. This is an open access article distributed under the Creative Commons Attribution License, which permits unrestricted use, distribution, and reproduction in any medium, provided the original work is properly cited.

The effect of an antioxidative peptide Met-Lys-Ala-Val-Cys-Phe-Ser-Leu (MKAVCFSL) on oxidative stress in Caco-2 cell lines was investigated. Caco-2 cells exposed to excess oxidative stress could be restored when pretreated with the peptide. Reactive oxygen species (ROS) and malondialdehyde (MDA) within the cells could be scavenged by MKAVCFSL. The peptide could also enhance the activity of glutathione peroxidase (GPx), glutathione reductase (GR), and superoxide dismutase (SOD), while catalase (CAT) activity did not show a significant difference between treatment and control samples. Meanwhile, it was observed that peptide treatment increased the concentration of glutathione (GSH). Yet the content of glutathione disulfide (GSSG) was hardly affected. The stability of MKAVCFSL was also assessed and an intact peptide was observed after simulated gastrointestinal digestion. Part of the peptide was hydrolyzed into fragments including MKA, FSL, AVCFSL, and MKAVCF. This study demonstrated that MKAVCFSL derived from bighead carp hydrolysates could ameliorate oxidative stress to protect the Caco2 cells.

\section{Introduction}

Oxidative stress is defined as the potential biological damage caused by free radicals [1]; it demonstrates an excessive production of ROS that cannot be counteracted by the action of antioxidative protection systems of the cells. The imbalance between the oxidant species such as hydrogen peroxide $\left(\mathrm{H}_{2} \mathrm{O}_{2}\right)$, superoxide $\left(\mathrm{O}_{2}-\bullet\right)$, singlet oxygen $(1 / 2$ $\left.\mathrm{O}_{2}\right)$, and the hydroxyl radical $(\bullet \mathrm{OH})$ was mainly produced from the mitochondrion. The oxidant species may trigger specific factors responsible for oxidative damage in the cells including cellular proteins, membrane lipids, nucleic acids, and eventually cell death. This damage has a correlation with several pathologies like cardiovascular, cancer, diabetes, and inflammatory diseases [2].

All cells possess elaborate antioxidant systems constitutive of interacting various weight components. Among them, SOD, GPx, and CAT play a significant role in scavenging ROS. Increased oxidative stress associated with the disease is often related to a depletion in enzymatic and nonenzymatic antioxidants [3], which reduced the ability to protect against excess ROS exposure. Therefore, extra antioxidants are supposed to be utilized as direct scavengers of free radicals, as inhibitors of lipid peroxidation, and so on [4]. Therefore, researchers' interest in the identification, characterization, and application of antioxidants has increased to protect organisms from oxidative stress. Natural sources have been specifically considered because they appear to be safer for consumers than synthetic antioxidants, such as butylated hydroxytoluene (BHT), which have shown to be carcinogenic [5]. Food-derived antioxidant peptides have been purified from many protein hydrolysates such as sardinelle (Sardinella aurita) [6], chickpea (Cicer arietinum L.) protein [7], blue mussel (Mytilus edulis) protein [8], and 
barley glutelin [9]. Yet, antioxidant peptide identified from freshwater fish was limited.

In our previous study, we identified an antioxidant peptide MKAVCFSL from flesh hydrolysate of bighead carp (Hypophthalmichthys nobilis), which had effective DPPH radical scavenging activity, ferrous ions $\left(\mathrm{Fe}^{2+}\right)$ chelating activity, and reducing power [10]. However, there is a lack of research on the evaluation of antioxidant activity at the cellular level. In this study, the protective role of this antioxidant peptide against $\mathrm{H}_{2} \mathrm{O}_{2}$-induced oxidative stress was further evaluated in Caco- 2 cell lines since the intestinal epithelium is the interface between the organism and its luminal environment, which is prone to suffer oxidative stress [11]. Contents of cellular ROS and MDA were assessed to study the antioxidant capacity at the cellular level. The enzyme activities, including SOD, GPx, GR, and CAT, and cellular antioxidant GSH were investigated to evaluate whether this peptide also initiated the cellular antioxidant system to protect Caco- 2 cells against $\mathrm{H}_{2} \mathrm{O}_{2}$-mediated cell death. Besides, simulated gastrointestinal digestion was performed to evaluate the stability of the peptide before in vivo experiments.

\section{Materials and Methods}

2.1. Materials. Caco-2 cells were purchased from American Type Culture Collection (ATCC, Manassas, VA, USA). Dulbecco's modified Eagle's medium (DMEM) was the product of Hyclone (Logan, UT). Fetal bovine serum (FBS) was purchased from Gibco (New York, NY, USA). The flasks for growing cells were acquired from Corning Costar (New York, NY, USA). MKAVCFSL was synthesized by Jietai Synpeptide Co., Ltd. (Shanghai, China). $\mathrm{H}_{2} \mathrm{O}_{2}$ and all other chemicals were purchased from China National Medicines Corporation Ltd. (Shanghai, China). Bicinchoninic acid (BCA) protein was from Solarbio (Beijing, China). Catalase, SOD, cellular GPx, GR, and GSH/GSSG assay kits were purchased from Beyotime Institute of Biotechnology (Jiangsu, China).

\subsection{Simulated Gastrointestinal Digestion. In vitro pepsin-} pancreatin-simulated digestion was performed according to the method described by Samaranayaka with slight modifications [12]. The peptide MKAVCFSL $(50 \mu \mathrm{g} / \mathrm{mL})$ was initially dissolved in distilled water, and the $\mathrm{pH}$ was adjusted to 2.0 using $5 \mathrm{M} \mathrm{HCl}$. Pepsin was mixed with the peptide in a ratio of $1: 100 \mathrm{w} / \mathrm{w}$ of the substrate, and the mixture was incubated at $37^{\circ} \mathrm{C}$ for $1 \mathrm{~h}$. After that, the $\mathrm{pH}$ was adjusted to 5.3 using saturated $\mathrm{NaHCO}_{2}$ solution and was further augmented to 7.5 with $5 \mathrm{M} \mathrm{NaOH}$. Subsequently, pancreatin (enzyme: substrate ratio, 1:50 w/w) was added to the mixture, which was incubated again at the temperature of $37^{\circ} \mathrm{C}$ for $2 \mathrm{~h}$. Aliquots of the digested samples were collected at $1 \mathrm{~h}, 2 \mathrm{~h}$, and $3 \mathrm{~h}$. The enzymatic reaction was terminated by immerging the samples in a $95^{\circ} \mathrm{C}$ water bath for $10 \mathrm{~min}$ and cooling the samples to room temperature on ice. The digested samples were used to evaluate the stability utilizing LC-MS/MS analysis.
2.3. Determination of Amino Acid Sequence by LC-MS/MS. After simulated gastrointestinal digestion, the molecular mass and peptide sequencing analysis was performed using a Thermo Q-Exactive high-resolution mass spectrometer (Thermo Scientific, Waltham, MA, USA) in positive ion mode with a capillary temperature of $320^{\circ} \mathrm{C}$ and a $2 \mathrm{kV}$ spray voltage applied to the emitter. The following electrospray ionization (ESI) conditions were utilized for MS analysis: a high resolution (70,000 FWHM) MS full scan (m/z 300-2000 Da) was performed to select the 10 most intense ions prior to $\mathrm{MS} / \mathrm{MS}$ analysis using $10 \mathrm{eV}$ energy collisional dissociation.

2.4. Induction of Oxidative Stress. The Caco-2 cells' cultivation was conducted at the concentration of $3.2 \times 10^{5}$ cells/ $\mathrm{mL}$ in 24-well culture plates for 3 days and the fresh medium was replaced daily. Prior to oxidative induction, Caco- 2 cells were incubated with antioxidant peptide for $24 \mathrm{~h}$ and then washed twice with phosphate-buffered saline (PBS), pH 7.2. After that, the cells were incubated for $2 \mathrm{~h}$ with $1 \mathrm{mM} \mathrm{H}_{2} \mathrm{O}_{2}$ to induce oxidative stress. The cells were treated as follows: medium treatment without $\mathrm{H}_{2} \mathrm{O}_{2}$ and peptide (control 1: $\mathrm{C} 1$ ), $\mathrm{H}_{2} \mathrm{O}_{2}$ treated only (control 2: $\mathrm{C} 2$ ), peptide treated only (sample 1: S1), and medium treatment with $\mathrm{H}_{2} \mathrm{O}_{2}$ and peptide (sample 2: S2). The cells were then lysed with cell lysis buffer (Beyotime, Jiangsu, China) and centrifuged at $10,000 \mathrm{~g}$ and $4^{\circ} \mathrm{C}$ for $10 \mathrm{~min}$. The supernatant was collected and stored at $-80^{\circ} \mathrm{C}$ until further experiment. The cell lysate protein concentration was measured using the Bicinchoninic Acid (BCA) Protein Assay Kit (Solarbio, Beijing, China).

2.5. Cytotoxicity Assay. Cell Counting Kit-8 (CCK-8) from Solarbio (Beijing, China) was used to measure the cytotoxicity of MKAVCFSL in Caco-2 cells. The peptide was dissolved in DMEM and then diluted in a culture medium and added to the cultures $24 \mathrm{~h}$ after cell seeding. Cells were treated as the method of 2.2 , after which $10 \mu \mathrm{L}$ of CCK- 8 was added to each well, and the plates were further incubated for $4 \mathrm{~h}$. Thereafter, the absorbance was read using a microplate reader (Bio-Tek, Synergy HT, USA) with $450 \mathrm{~nm}$. The viability of cells was expressed as a percentage of the viability of cells in $\mathrm{C} 1$ treatment.

2.6. Determination of Intracellular ROS. The intracellular ROS contents inside the Caco-2 cells were measured according to the instruction of the ROS Assay Kit. Cells were seeded in 96-well plates at a concentration of $2.5 \times 10^{5}$ cells/ $\mathrm{mL}$. Cultured cells were treated as the method of 2.4. After incubation, $10 \mu \mathrm{M}$ DCFH-DA was added to the wells and then incubated at $37^{\circ} \mathrm{C}$ and $5 \% \mathrm{CO}_{2}$ for $20 \mathrm{~min}$, and cells were then washed with DMEM without FBS for three times. Fluorescence readings were taken at excitation and emission wavelengths of 488 and $525 \mathrm{~nm}$ using a Multi-Detection Microplate Reader (Bio-Tek, Synergy HT, USA), respectively. Cellular ROS levels were expressed as fluorescence intensity. 
2.7. Measurement of Lipid Peroxidation. The cellular MDA content was evaluated to investigate the level of lipid peroxidation under oxidative stress according to the method of the MDA Assay Kit (Solarbio, Beijing). $100 \mu \mathrm{L}$ cell lysate supernatant was mixed with $200 \mu \mathrm{L}$ MDA working solution and heated at $100^{\circ} \mathrm{C}$ for $30 \mathrm{~min}$. After cooling the mixture to room temperature, samples were centrifuged at $10,000 \mathrm{~g}$ for $10 \mathrm{~min}$. The absorbance at $532 \mathrm{~nm}$ and $600 \mathrm{~nm}$ was measured in a 96-well plate, respectively. The results of the MDA assay were expressed as nanomoles of MDA per milligram of protein.

\subsection{Effect of MKAVCFSL on Endogenous Antioxidant Defence Systems in Caco-2 Cells under Oxidative Stress}

2.8.1. Measurement of GSH and GSSG Concentration. Cellular GSH and GSSG were evaluated according to the direction of GSH and GSSG Assay Kit. Cell lysate supernatants were obtained by being rapidly freezethawed twice with liquid nitrogen and $37^{\circ} \mathrm{C}$ water baths and then centrifuged at $10,000 \mathrm{~g}$ for $10 \mathrm{~min}$ at $4^{\circ} \mathrm{C} .10 \mu \mathrm{L}$ total GSH and GSSG standards were mixed with $150 \mu \mathrm{L}$ of $100 \mathrm{mM}$ PBS containing $4 \mathrm{mM}$ EDTA, $0.2 \mathrm{mM}$ NADPH, $0.5 \mathrm{mM}$ DTNB, and 100 units $/ \mathrm{mL}$ glutathione reductase in a 96-well plate, respectively. Sample supernatants and supernatants which eliminated reduced GSH were mixed with the same PBS as well. The mixture was incubated for $5 \mathrm{~min}$ at room temperature and $0.5 \mathrm{mg} / \mathrm{mL} \mathrm{NADPH}$ was added to each corresponding well. The absorbance was read at $412 \mathrm{~nm}$. The concentration of total glutathione and GSSG in the cell lysate was calculated using a standard curve and GSH concentration was calculated from total glutathione contents deducted GSSG contents.

2.8.2. Glutathione Peroxidase (GPx) Activity. GPx was assessed according to the procedure of the Cellular Glutathione Peroxidase Assay Kit. Briefly, $10 \mu \mathrm{L}$ cell lysate was mixed with $175 \mu \mathrm{L} 100 \mathrm{mM}$ potassium phosphate buffer $(\mathrm{pH}$ 7.0) containing $1 \mathrm{mM}$ EDTA and $11 \mu \mathrm{L}$ of GR solution which contains $30 \mathrm{mM}$ NADPH, $84 \mathrm{mM} \mathrm{GSH}$, and $1 \mu \mathrm{L} 5 \mathrm{U} / \mu \mathrm{L}$ GR. $4 \mu \mathrm{L} 15 \mathrm{mM} \mathrm{H} 2 \mathrm{O} 2$ was added to the solution mixture. The absorbance was monitored at $340 \mathrm{~nm}$ every $2 \mathrm{~min}$ for $10 \mathrm{~min}$. The activity of GPx within the cell was calculated using a standard curve and expressed as milliunit of GPx per milligram of protein. One unit of activity was expressed as the conversion of $1 \mathrm{mM} / \mathrm{min} \mathrm{NADPH}$ to NADP+.

2.8.3. Glutathione Reductase (GR) Activity. GR activity was determined using the method described by the Glutathione Reductase Assay Kit. In brief, $20 \mu \mathrm{L}$ cell lysate was added to $100 \mathrm{mM}$ PBS $(0.85 \mathrm{~mL}, \mathrm{pH}$ 7.5) containing $1 \mathrm{mM}$ EDTA and $2.32 \mathrm{mM}$ GSSG. NADPH $(2 \mathrm{mM}, 10 \mu \mathrm{L})$ was mixed with the solution and the absorbance of $340 \mathrm{~nm}$ was read every $1 \mathrm{~min}$ for $5 \mathrm{~min}$ at $25^{\circ} \mathrm{C}$ using a Multi-Detection Microplate Reader (Bio-Tek, Synergy HT, USA). Changes in the rate of absorbance were converted into units of GR per milligram of protein using a molar extinction coefficient of $6.22 \mathrm{mM}^{-1} \mathrm{~cm}^{-1}$.
One unit of activity was defined as the reduction of $1 \mu \mathrm{mol} / \mathrm{min}$ GSSG.

2.8.4. Superoxide Dismutase Assay. SOD activity was investigated utilizing a Total Superoxide Dismutase Assay Kit according to the manufacture's instruction. The water-soluble tetrazolium-8 (WST-8) method, which is more stable and sensitive, is currently used in the determination of SOD activity. Absorbance was determined at $450 \mathrm{~nm}$. Results were expressed as units milligram of protein where protein content was determined by the BCA method. One unit of SOD is defined as the quantity of the enzyme in $20 \mu \mathrm{L}$ of the sample solution that inhibits the reduction reaction of WST8 with superoxide anion by $50 \%$.

2.8.5. Catalase Assay. In order to measure the level of catalase in Caco-2 cell lysate, the Catalase Activity Assay Colorimetric Kit was used according to the manufacturer's instructions. Absorbance was measured at $520 \mathrm{~nm}$ and results were expressed as units milligram of protein. One unit of catalase is defined as the amount of the enzyme that can catalyze $1 \mu \mathrm{mol} \mathrm{H}_{2} \mathrm{O}_{2}$ within 1 minute under the condition of $\mathrm{pH} 7$.

2.9. Statistical Analysis. Statistical analysis was performed with SPSS software, version 20 (SPSS Inc., Chicago, IL, USA), using one-way ANOVA followed by Duncan's multiple range test. Differences were considered at a significance level of $p<0.05$.

\section{Results and Discussion}

3.1. Evaluating the Stability of MKAVCFSL after Simulated Gastrointestinal Digestion. To investigate the stability of the peptide, LC-MS/MS was performed to identify the variation of MKAVCFSL. According to the RP-HPLC chromatogram in Figure 1, undigested MKAVCFSL was eluted at 33-35 min. After pepsin-pancreatin digestion, several new peaks appeared such as fractions from $28.44 \mathrm{~min}, 30.13 \mathrm{~min}$, and 37.55 min besides the MKAVCFSL peak. LC-MS/MS confirmed that new fragments MKA, FSL, AVCFSL, MKAVCF were released from MKAVCFSL after simulated gastrointestinal digestion. The majority of the peptide remained stable according to LC-MS/MS, which indicated the peptide had the ability to resist pepsin-pancreatin digestion. These results suggested MKAVCFSL was highly likely to successfully pass through the digestive tract and reach intestine to exert antioxidant activity pepsinpancreatin.

3.2. Analysis of Effects of MKAVCFSL on Cellular Viability, $R O S$, and MDA. Our previous study has confirmed that the MKAVCFSL peptide showed effective antioxidant activity such as DPPH scavenging activity, reducing power, and ferrous ions $\left(\mathrm{Fe}^{2+}\right)$ chelating activity [10]. Therefore, we highlighted if the antioxidant peptide could express good antioxidant activity at the cellular level. In our current study, 


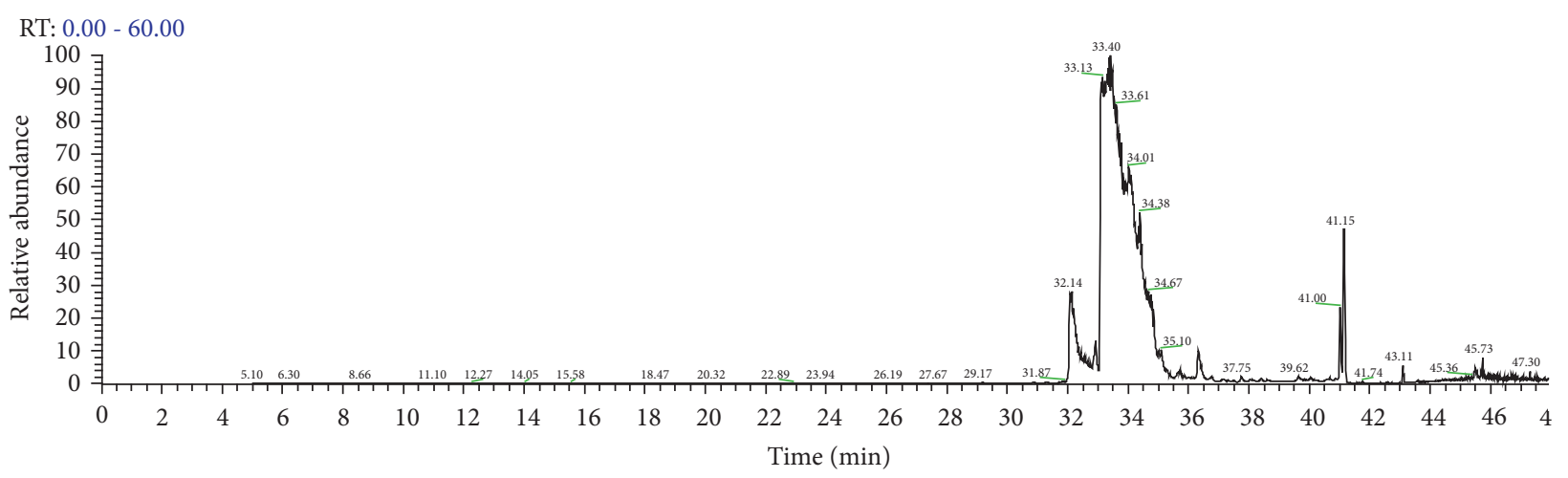

(a)

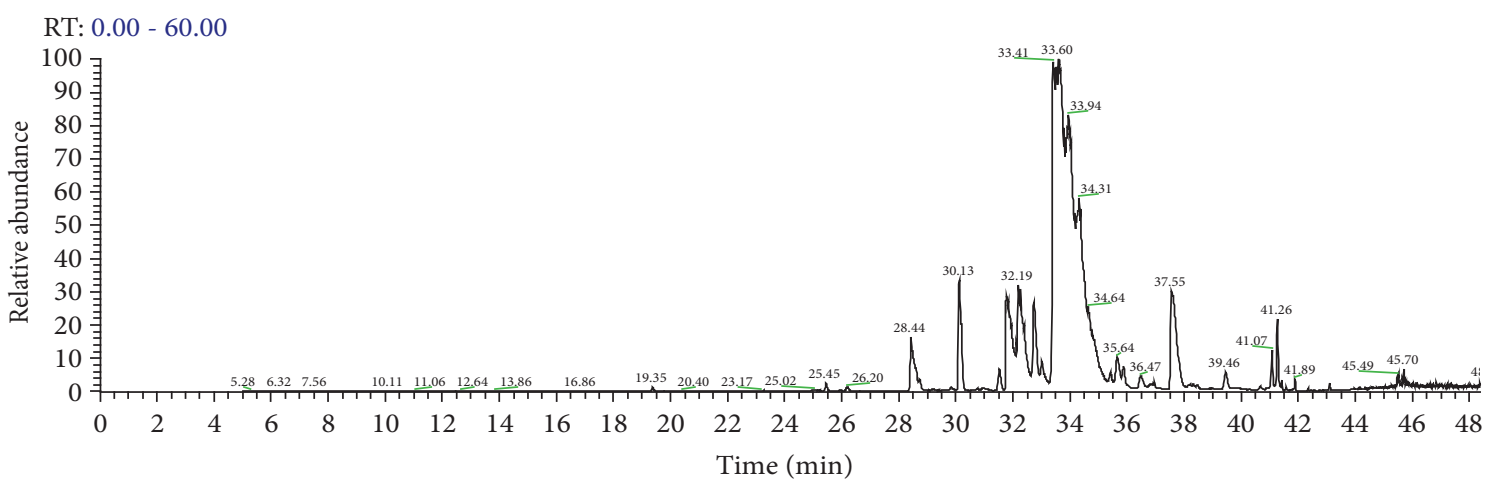

(b)

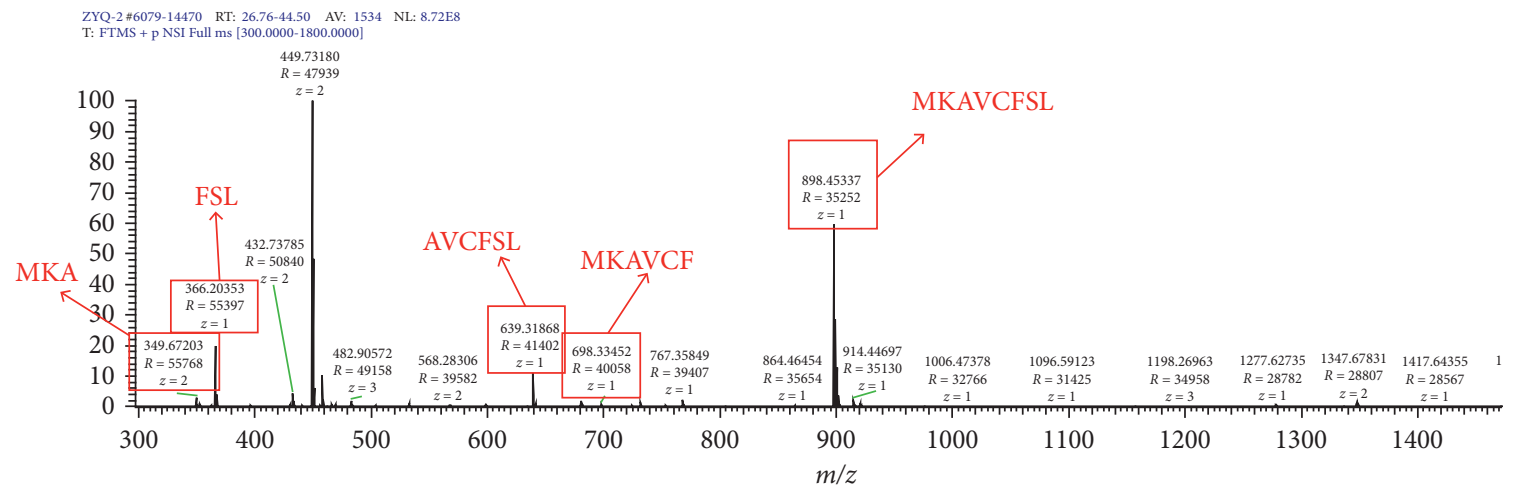

(c)

FIGURE 1: RP-HPLC and LC-MS/MS analysis of MKAVCFSL after simulated gastrointestinal digestion. (a) RP-HPLC chromatogram of undigested MKAVCFSL. (b) RP-HPLC chromatogram of MKAVCFSL after pepsin-pancreatin digestion. (c) LC-MS/MS identification of pepsin-precretin digested peptide.

Caco-2 cells were induced by $1 \mathrm{mM} \mathrm{H}_{2} \mathrm{O}_{2}$ which was excessive and impaired the cell viability detected by cytotoxicity assay (data not shown). Figure 2 has shown that when cells are treated with $\mathrm{H}_{2} \mathrm{O}_{2}$, the cell activity was inhibited significantly compared with $\mathrm{C} 1$ samples suggesting that the cells' ability to adapt to the addition of $\mathrm{H}_{2} \mathrm{O}_{2}$ in the media has been conquered. However, cell protection was achieved when cells were pretreated with $50 \mu \mathrm{g} / \mathrm{mL}$ MKAVCFSL (determined by cytotoxicity assay, data not shown) for $24 \mathrm{~h}$ since cell viability recovered from $(72.06 \pm 0.68) \%$ to $(89.18 \pm 3.54) \%$. It was interesting that the viability of cells with peptide treated alone could also be improved. Thus, the concentration of ROS and MDA, which were biomarkers of oxidative stress in Caco- 2 cells, was measured to investigate whether this phenomenon was associated with the peptide antioxidant activity or not. Figure 3 exhibited that intracellular ROS level expressed as fluorescence intensity has been increased after $\mathrm{H}_{2} \mathrm{O}_{2}$ treatment. While being pretreated with the peptide, ROS decreased to the untreated level. Meanwhile, peptide alone hardly influenced the ROS concentration, which indicated that the protective effect of the cells after $\mathrm{H}_{2} \mathrm{O}_{2}$ stimulation was related to antioxidant activity. MDA which was produced from lipid peroxidation could also further confirm the conclusion we have made. When Caco-2 cells were treated with $1 \mathrm{mM} \mathrm{H}_{2} \mathrm{O}_{2}$ for 2 hours, an almost 3 -fold increase in lipid peroxidation 
products was observed (from $(0.40 \pm 0.08) \mathrm{nmol} / \mathrm{mg}$ protein to $(1.15 \pm 0.08) \mathrm{nmol} / \mathrm{mg}$ protein) compared with the $\mathrm{C} 1$ sample. However, peptide significantly inhibited the formation of MDA to a concentration of $(0.77 \pm 0.06) \mathrm{nmol} /$ $\mathrm{mg}$ protein in stressed cells (S2 sample) when compared with C2 sample. These results were in accordance with those observed with peptides isolated from Hoki fish on human embryonic lung fibroblasts [13] and silver carp peptides in human intestinal epithelial Caco-2 cells [14]. Besides antioxidant peptides, the antioxidant effect of other food compositions was also highlighted such as ascorbic acid, tocopherols, arotenoids, and other varieties of polyphenols and flavonoids [15]. However, the study on foodderived antioxidant peptides that was evaluated at the cellular level was still limited. The results for the protective effect of MKAVCFSL in Caco-2 cells completed the noncellular antioxidant activity that we reported previously.

\subsection{Analysis of Antioxidant Enzymes Activity Pretreated with} $M K A V C F S L$. To investigate if the antioxidant peptide could also affect the internal antioxidant system of Caco-2 cells, various antioxidant enzymes including SOD, CAT, GPx, and GR as well as the endogenous antioxidant GSH were determined. SOD could contribute to converting superoxide to hydrogen peroxide, which is then decomposed by CAT or GPx into $\mathrm{H}_{2} \mathrm{O}$ [16]. Deleterious actions of $\mathrm{H}_{2} \mathrm{O}_{2}$ on Caco-2 cells were observed since SOD activity was inhibited for about 2 -folds compared with $\mathrm{C} 1$. The reduction in SOD activity is deemed to be caused by an interaction between $\mathrm{H}_{2} \mathrm{O}_{2}$ and a copper moiety within the SOD molecule. Hydroxyl and copper-bound radicals could be produced during the process, which oxidized histidine residues resulting in the denaturation of the SOD protein $[17,18]$. When preincubated with peptide for $24 \mathrm{~h}$, SOD activity showed no significant difference in S2 compared with $\mathrm{C} 2$ treatment, which suggested that peptide had the ability to protect the SOD from the $\mathrm{H}_{2} \mathrm{O}_{2}$ toxicity. It is deduced that the SOD-protecting effects of MKAVCFSL may be due to their possible chelation of surplus copper ions in the SOD complex preventing the metal from reacting with $\mathrm{H}_{2} \mathrm{O}_{2} \cdot \mathrm{H}_{2} \mathrm{O}_{2}$ stimulation, on the contrary, increased the catalase activities from $(0.33 \pm 0.06)$ units $\mathrm{min}^{-1} \mathrm{mg}^{-1}$ protein to $(0.55 \pm 0.04)$ units $\mathrm{min}^{-1} \mathrm{mg}^{-1}$ protein compared to the untreated baseline cells (Figure 4(b)). Catalase, as a primary defense enzyme against oxidative stress from exogenous, is a porphyrincontaining enzyme which catalyzes the decomposition of hydrogen peroxide to water and oxygen [19]. Therefore, it is reasonable that the activity of catalase increased to scavenging excessive $\mathrm{H}_{2} \mathrm{O}_{2}$. On the contrary, Shi et al. [20] have reported that CAT activity decreased after treated by $1 \mathrm{mM} \mathrm{H}_{2} \mathrm{O}_{2}$ because it is a high dose for CAT to completely decompose $\mathrm{H}_{2} \mathrm{O}_{2}$ into $\mathrm{H}_{2} \mathrm{O}$ [21]. The addition of the peptide had no significant effect $(p<0.05)$ on the CAT activity of normal cells and $\mathrm{H}_{2} \mathrm{O}_{2}$-challenged cells. These results were similar to O'Sullivan et al. [22] and Kim et al. [23].

GPx also plays a critical role in protecting the cells from oxidative stress damage induced by a high concentration of
$\mathrm{H}_{2} \mathrm{O}_{2}$ [21, 24]. GPx utilizes GSH to degrade $\mathrm{H}_{2} \mathrm{O}_{2}$ into $\mathrm{H}_{2} \mathrm{O}$ and converts GSH into GSSG. GR catalyzes the decrease of GSSG to the GSH in its sulfhydryl form. Therefore, GSH can regenerate through the cyclic action between GPx and GR [25]. In normal cells without $\mathrm{H}_{2} \mathrm{O}_{2}$ stimulation, peptides did not enhance GPx and GR activity significantly (Figure 4). After the addition of MKAVCFSL, the activity of GPx, GR in the cells $\mathrm{H}_{2} \mathrm{O}_{2}$ treatment were increased with presented in Figures 4(c) and 4(d). This indicated that the peptide could not enhance the GPx and GR activity directly. The protective effect was involved in the removal of oxidative factors that occurred in the cellular metabolic environment. Mammalian GPx1-4 are selenoproteins with selenocysteine (Sec) in the catalytic center, of which GPx2 is mainly expressed in the intestinal epithelium [26]. The presence of Sec as the catalytic moiety of GPx was suggested to guarantee a fast reaction with the hydroperoxide and fast reducibility by GSH [27]. The selenol $(-\mathrm{SeH})$ in SecGPxs reacts in form of a selenolate with $\mathrm{H}_{2} \mathrm{O}_{2}$ to selenenic acid $(-\mathrm{SeOH})$ which is reduced back to -SeH by two GSH forming GSSG and $\mathrm{H}_{2} \mathrm{O}$ $[28,29]$. Thus, MKAVCFSL might protect Sec in GPx from being attacked by $\mathrm{H}_{2} \mathrm{O}_{2}$. GR contains highly conserved domains, one of which can bind reduced nicotinamide adenine dinucleotide phosphate $(\mathrm{NADPH})$ sustaining reduced GSH in cells. The antioxidant activity of MKAVCFSL may decrease the NAPDH converting into $\mathrm{NADP}^{+}$contributing to the GR activity. Some studies have also verified the impact of oligopeptide and polyphenols on antioxidant enzyme activities in cells. It is demonstrated that the egg-derived peptide elevated GR, GST, and CAT enzymatic activity in human intestinal cells [30]. Other researchers have demonstrated phenolic compounds from olive oil significantly enhanced GR and GP activities in macrophages and verified that the impact of flavonoids on antioxidant protein expression was genespecific in Caco-2 cells $[31,32]$.

3.4. Analysis of Cellular Antioxidants GSH. GSH is a tripeptide consisting of glutamine, cysteine, and glycine and is a key component in the nonenzymatic antioxidant mechanism of cells [33]. The present study has found that GSH level was significantly decreased in the cells treated with $1 \mathrm{mM} \mathrm{H}_{2} \mathrm{O}_{2}$ only (Figure 5) compared to untreated cells. However, pretreatment of peptide supplementation for $24 \mathrm{~h}$ before the addition of $\mathrm{H}_{2} \mathrm{O}_{2}$ restored $\mathrm{GSH}$ levels significantly. Meanwhile, MKAVCFSL alone could also elevate the GSH concentration in the cells. While GSSG, the oxidized state of glutathione, was not significantly influenced by the peptide without $\mathrm{H}_{2} \mathrm{O}_{2}$ stimulation. $\mathrm{H}_{2} \mathrm{O}_{2}$ alone augmented the concentration of GSSG from $(3.06 \pm 0.41) \mu \mathrm{M}$ to $(4.92 \pm 0.63) \mu \mathrm{M}$ compared to the $\mathrm{C} 1$ sample. Nevertheless, decreased GSSG concentration was observed in the S2 sample. Increased GSH concentration was unexpectedly in S1 since the activity of GPx and GR was not significantly different from untreated samples $(\mathrm{C} 1)$. We inferred that the peptides may have a positive effect on GSH synthesis. Increased GSSG in C2 samples was also interesting because GPx and GR activity were both inhibited by excessive $\mathrm{H}_{2} \mathrm{O}_{2}$. 


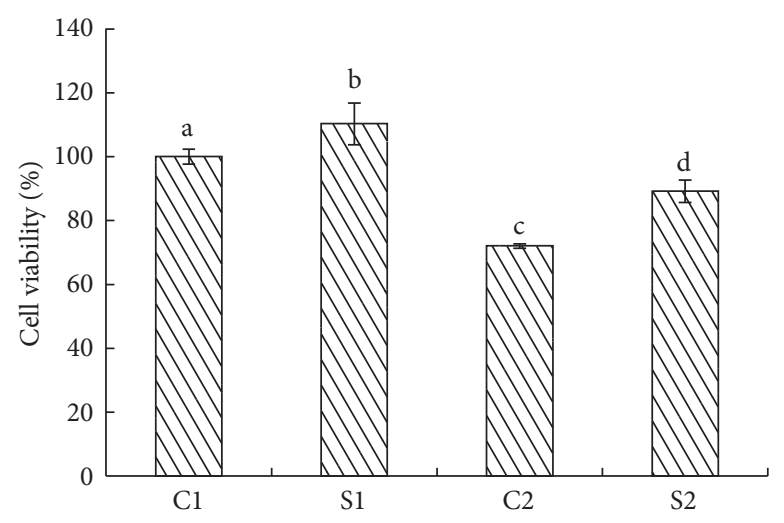

Figure 2: Viability of Caco-2 cells after different treatment as follows: medium treatment without $\mathrm{H}_{2} \mathrm{O}_{2}$ and peptide (control 1: C1), $\mathrm{H}_{2} \mathrm{O}_{2}$ treated only (control 2: C2), peptide treated only (sample 1: S1), and medium treatment with $\mathrm{H}_{2} \mathrm{O}_{2}$ and peptide (sample 2: S2). The viability of cells was expressed as a percentage of the viability of cells in $\mathrm{C} 1$ treatment. Results were the means \pm SD from three independent experiments. Different small letters indicated significant differences between groups $(p<0.05)$.

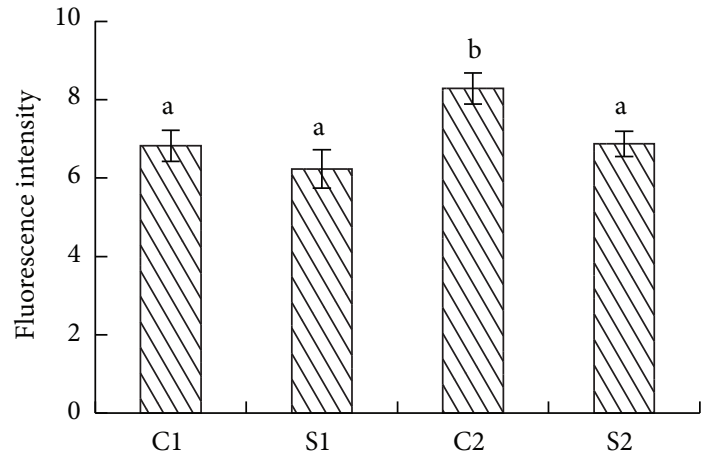

(a)

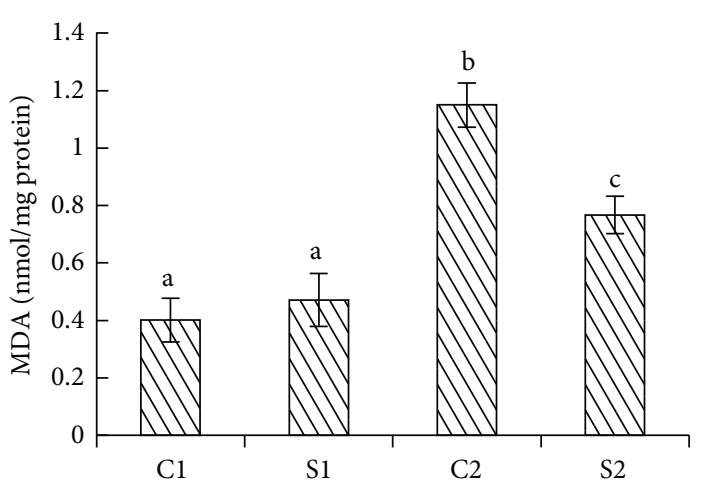

(b)

FIgURE 3: Effects of MKAVCFSL on (a) intracellular ROS level and (b) MDA concentration C1: control 1, medium treatment without $\mathrm{H}_{2} \mathrm{O}_{2}$ and peptide; S1: sample 1, peptide treated only; C2: control 2, $\mathrm{H}_{2} \mathrm{O}_{2}$ treated only; S2: sample 2, medium treatment with $\mathrm{H}_{2} \mathrm{O}_{2}$ and peptide. ROS level was expressed as fluorescence intensity. Results are the means \pm SD from three independent experiments. Different small letters indicate significant differences between groups $(p<0.05)$.

It could be speculated that the GPx showed effectively antioxidant activity to dispose oxidant stress initially. Thus, plenty of GSH was converted into GSSH. Besides, the toxicity of $\mathrm{H}_{2} \mathrm{O}_{2}$ decreased GR activity, which also prohibited the GSSH from reducing back to GSH, thus bringing about the accumulation of GSSH. The decreased GSSH in S2 was in accordance with the restored activity of GR, which could catalyze GSSG to form GSH at high efficiency to promote GSH level in the cells. MKAVCFSL had the potential for normal activity and functionality in the $\mathrm{H}_{2} \mathrm{O}_{2}$ model system to allow cells to maintain a balanced redox. These results validate the MKAVCFSL could protect the cells from oxidative stress damage.

Generally, MKAVCFSL enhanced GPx activity for subsequent lipid hydroperoxide and ROS induced detoxification using GSH and increased GR activity to regenerate GSH from GSSG. It also contributed to SOD activity without the addition of $\mathrm{H}_{2} \mathrm{O}_{2}$, but CAT was not influenced. The synergistic actions of cellular antioxidants, antioxidant enzymes, and the peptide efficiently ameliorated the damage of oxidative stress. The protective effect of MKAVCFSL against
$\mathrm{H}_{2} \mathrm{O}_{2}$-induced injury may be due to two reasons correlated to its amino acids composition. On one hand, a peptide having radical scavenging activity can suppress free radicalmediated oxidation [34]. As a previous study earlier, MKAVCFSL contains more aromatic and hydrophobic amino acids and exhibited higher radical scavenging activity, which may be responsible for its protection [20]. In particular, phenylalanine and methionine residues in peptides and proteins were regarded as free radical scavengers in vivo [35]. On the other, some studies have exhibited that some peptides can prevent oxidative stress through reducing antioxidant enzyme capacity $[30,34]$, which concurred with our results. Indeed, the cellular regulation of the antioxidant system is complicated and involves intricate signaling networks which is not fully understood. Besides, different signaling networks enhance the complexity and increase difficulties to understand redox control and related processes. Although the novel peptide was proved to have effective antioxidant activity, it is necessary to conduct a profound investigation on the relationship between oxidative stress and the antioxidant activity in vivo. 


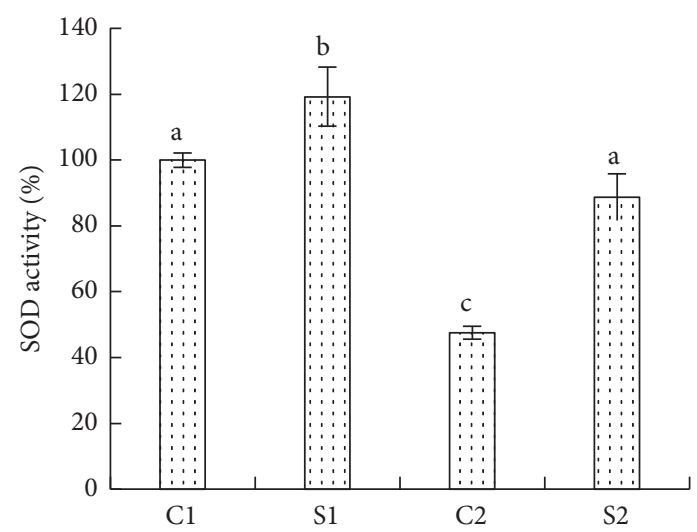

(a)

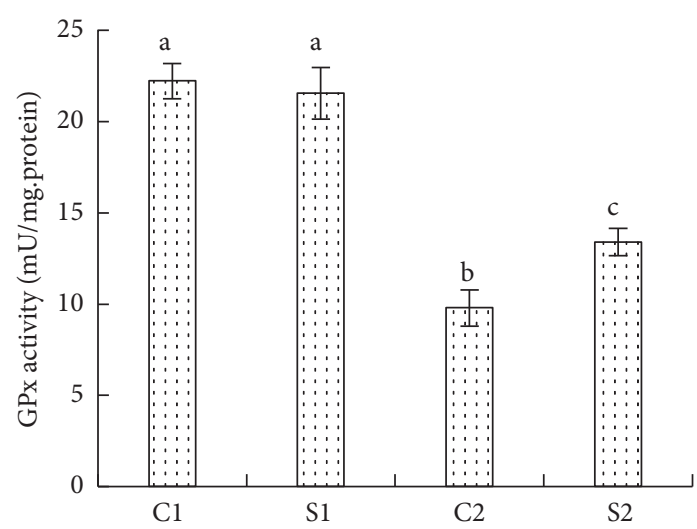

(c)

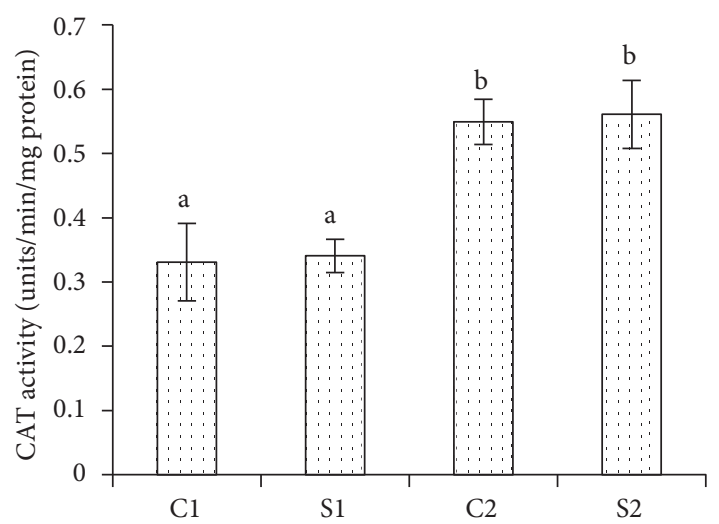

(b)

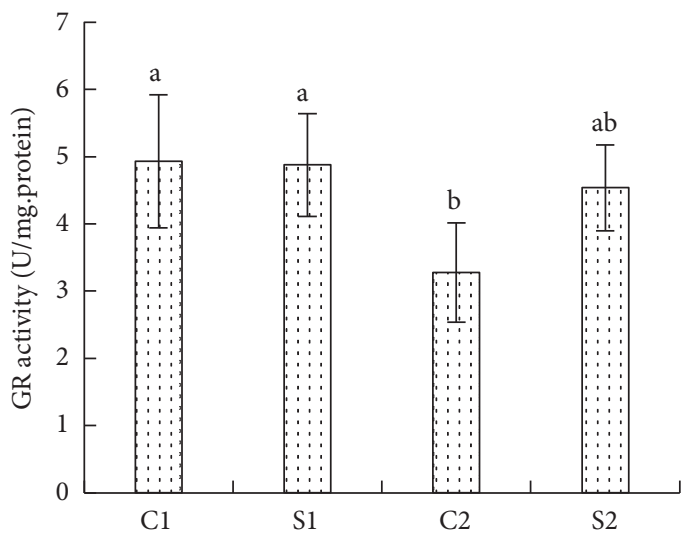

(d)

FIGURE 4: Effects of MKAVCFSL on the cellular antioxidant enzyme. (a) SOD activity, (b) CAT activity, (c) GPx activity, and (d) GR activity. $\mathrm{C} 1$ : control 1, medium treatment without $\mathrm{H}_{2} \mathrm{O}_{2}$ and peptide; S1: sample 1, peptide treated only; $\mathrm{C} 2$ : control 2, $\mathrm{H}_{2} \mathrm{O}_{2}$ treated only; S2: sample 2, medium treatment with $\mathrm{H}_{2} \mathrm{O}_{2}$ and peptide. Results are the means $\pm \mathrm{SD}$ from three independent experiments. Different small letters indicate significant differences between groups $(p<0.05)$.

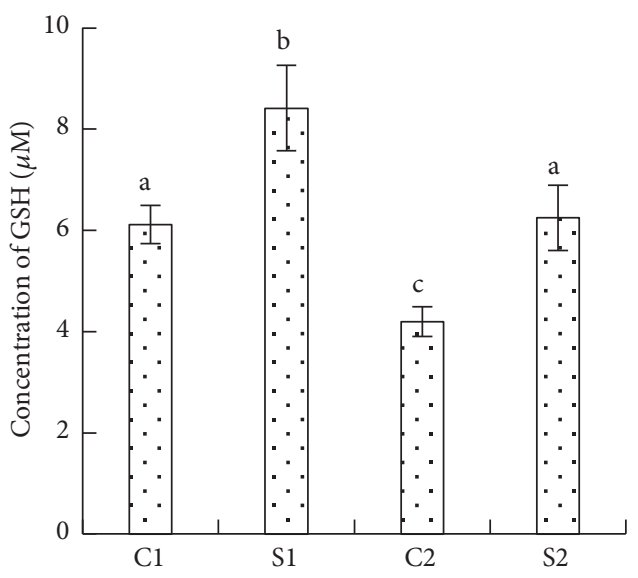

(a)

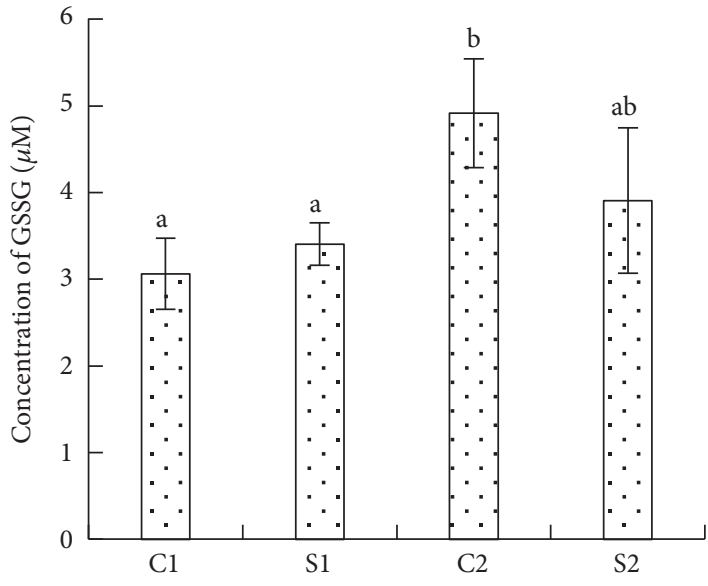

(b)

Figure 5: Effects of MKAVCFSL on the cellular GSH and GSSG. (a) GSH concentration. (b) GSSG concentration. C1: control 1, medium treatment without $\mathrm{H}_{2} \mathrm{O}_{2}$ and peptide; S1: sample 1, peptide treated only; C2: control 2, $\mathrm{H}_{2} \mathrm{O}_{2}$ treated only; S2: sample 2, medium treatment with $\mathrm{H}_{2} \mathrm{O}_{2}$ and peptide. Results are the means $\pm \mathrm{SD}$ from three independent experiments. Different small letters indicate significant differences between groups $(p<0.05)$. 


\section{Conclusion}

This study demonstrated that MKAVCFSL derived from bighead carp protein hydrolysates can remain stable through simulated gastrointestinal digestion, although part of the peptides were degraded into smaller fragments. The peptide could effectively scavenge ROS and MDA within the Caco-2 cells. Meanwhile, after being pretreated with the peptide, upregulation of the activity of several cellular antioxidant enzymes was observed including GPx, GR, and SOD in $\mathrm{H}_{2} \mathrm{O}_{2}$-induced Caco-2 cells. However, CAT was not influenced significantly. In addition, the concentration of endogenous antioxidant GSH was also increased, led by MKAVCFSL. In summary, this octapeptide displayed protective effects in Caco- 2 cells and may be a potential protective agent or food additives against oxidative stress.

\section{Data Availability}

The data used to support the findings of this study are included within the article.

\section{Conflicts of Interest}

The authors declare that they have no conflicts of interest.

\section{Acknowledgments}

This work was supported by the National Key Research and Development Program of China (2019YFC1606200, 2016YFD0400401).

\section{References}

[1] P. Kovacic and J. D. Jacintho, "Mechanisms of carcinogenesis focus on oxidative stress and electron transfer," Current Medicinal Chemistry, vol. 8, no. 7, pp. 773-796, 2001.

[2] A. M. Pisoschi and A. Pop, "The role of antioxidants in the chemistry of oxidative stress: a review," European Journal of Medicinal Chemistry, vol. 97, pp. 55-74, 2015.

[3] I. Dalle-Donne, R. Rossi, R. Colombo, D. Giustarini, and A. Milzani, "Biomarkers of oxidative damage in human disease," Clinical Chemistry, vol. 52, no. 4, pp. 601-623, 2006.

[4] Y. Zhang, G. Sun, M. Yang et al., "Chronic accumulation of cadmium and its effects on antioxidant enzymes and malondialdehyde in Oxya chinensis (Orthoptera: Acridoidea)," Ecotoxicology and Environmental Safety, vol. 74, no. 5, pp. 1355-1362, 2011.

[5] J. Pokorný, "Are natural antioxidants better - and safer - than synthetic antioxidants?” European Journal of Lipid Science and Technology, vol. 109, no. 6, pp. 629-642, 2007.

[6] A. Bougatef, N. Nedjar-Arroume, L. Manni et al., "Purification and identification of novel antioxidant peptides from enzymatic hydrolysates of sardinelle (Sardinella aurita) byproducts proteins," Food Chemistry, vol. 118, no. 3, pp. 559-565, 2010.

[7] T. Zhang, Y. Li, M. Miao, and B. Jiang, "Purification and characterisation of a new antioxidant peptide from chickpea (Cicer arietium L.) protein hydrolysates," Food Chemistry, vol. 128, no. 1, pp. 28-33, 2011.

[8] B. Wang, L. Li, C.-F. Chi, J.-H. Ma, H.-Y. Luo, and Y.-F. Xu, "Purification and characterisation of a novel antioxidant peptide derived from blue mussel (Mytilus edulis) protein hydrolysate," Food Chemistry, vol. 138, no. 2-3, pp. 1713-1719, 2013.

[9] Y. Xia, F. Bamdad, M. Gänzle, and L. Chen, "Fractionation and characterization of antioxidant peptides derived from barley glutelin by enzymatic hydrolysis," Food Chemistry, vol. 134, no. 3, pp. 1509-1518, 2012.

[10] C. Zhang, Y. Zhang, Z. Wang, S. Chen, and Y. Luo, "Production and identification of antioxidant and angiotensinconverting enzyme inhibition and dipeptidyl peptidase IV inhibitory peptides from bighead carp (Hypophthalmichthys nobilis) muscle hydrolysate," Journal of Functional Foods, vol. 35, pp. 224-235, 2017.

[11] M. L. Circu and T. Y. Aw, "Intestinal redox biology and oxidative stress," Seminars in Cell \& Developmental Biology, vol. 23, no. 7, pp. 729-737, 2012.

[12] A. G. P. Samaranayaka, D. D. Kitts, and E. C. Y. Li-Chan, "Antioxidative and angiotensin-I-converting enzyme inhibitory potential of a Pacific Hake (Merluccius productus) fish protein hydrolysate subjected to simulated gastrointestinal digestion and Caco-2 Cell permeation," Journal of Agricultural and Food Chemistry, vol. 58, no. 3, pp. 1535-1542, 2010.

[13] S.-Y. Kim, J.-Y. Je, and S.-K. Kim, "Purification and characterization of antioxidant peptide from hoki (Johnius belengerii) frame protein by gastrointestinal digestion," The Journal of Nutritional Biochemistry, vol. 18, no. 1, pp. 31-38, 2007.

[14] Z. Saiyi, M. Changwei, Y. C. Lin, and L. Yongkang, "Antioxidant properties of peptide fractions from silver carp (Hypophthalmichthys molitrix) processing by-product protein hydrolysates evaluated by electron spin resonance spectrometry," Food Chemistry, vol. 126, pp. 1636-1642, 2011.

[15] M. Serafini, R. Bellocco, A. Wolk, and A. M. Ekström, "Total antioxidant potential of fruit and vegetables and risk of gastric cancer,” Gastroenterology, vol. 123, no. 4, pp. 985-991, 2002.

[16] T. Finkel and N. J. Holbrook, "Oxidants, oxidative stress and the biology of ageing," Nature, vol. 408, no. 6809, pp. 239-247, 2000.

[17] R. C. Bray, S. A. Cockle, E. M. Fielden, P. B. Roberts, G. Rotilio, and L. Calabrese, "Reduction and inactivation of superoxide dismutase by hydrogen peroxide," Biochemical Journal, vol. 139, no. 1, pp. 43-48, 1974.

[18] O. I. Aruoma, "Free radicals, oxidative stress, and antioxidants in human health and disease," Journal of the American Oil Chemists' Society, vol. 75, no. 2, pp. 199-212, 1998.

[19] E. K. Hodgson and I. Fridovich, "The Interaction of bovine erythrocyte superoxide dismutase with hydrogen peroxide. Inactivation of the enzyme," Biochemistry, vol. 14, no. 24, pp. 5294-5299, 1975.

[20] Y. Shi, J. Kovacs-Nolan, B. Jiang, R. Tsao, and Y. Mine, "Antioxidant activity of enzymatic hydrolysates from eggshell membrane proteins and its protective capacity in human intestinal epithelial Caco-2 cells," Journal of Functional Foods, vol. 10, pp. 35-45, 2014.

[21] H. Masaki, Y. Okano, and H. Sakurai, "Differential role of catalase and glutathione peroxidase in cultured human fibroblasts under exposure of H 2 O 2 or ultraviolet B light," Archives of Dermatological Research, vol. 290, no. 3, pp. 113-118, 1998.

[22] A. M. O’Sullivan, Y. C. O’Callaghan, M. N. O’Grady et al., “In vitro and cellular antioxidant activities of seaweed extracts prepared from five brown seaweeds harvested in spring from the west coast of Ireland," Food Chem, vol. 126, pp. 1064-1070, 2011. 
[23] L. Kim, Y. Kim, O. Kwon, and J. Y. Kim, "Antioxidant activities of ethanolic and acidic ethanolic extracts of astringent persimmon in $\mathrm{H}_{2} \mathrm{O}_{2}$-stimulated Caco-2 human colonic epithelial cells," Food Science and Biotechnology, vol. 26, no. 4, pp. 1085-1091, 2017.

[24] S. S. K. Wijeratne, S. L. Cuppett, and V. Schlegel, "Hydrogen peroxide induced oxidative stress damage and antioxidant enzyme response in Caco-2 human colon cells," Journal of Agricultural and Food Chemistry, vol. 53, no. 22, pp. 8768$8774,2005$.

[25] A. Meister, "Glutathione metabolism and its selective modification," Journal of Biological Chemistry, vol. 263, no. 33, pp. 17205-17208, 1988.

[26] F. F. Chu, J. H. Doroshow, and R. S. Esworthy, "Expression, characterization, and tissue distribution of a new cellular selenium-dependent glutathione peroxidase, GSHPx-GI," Journal of Biological Chemistry, vol. 268, no. 4, pp. 2571-2576, 1993.

[27] L. Flohé and M. Maiorino, "Glutathione peroxidases," Biochimica et Biophysica Acta, vol. 1830, pp. 399-404, 2013.

[28] S. Toppo, L. Flohé, F. Ursini, S. Vanin, and M. Maiorino, "Catalytic mechanisms and specificities of glutathione peroxidases: variations of a basic scheme," Biochimica et Biophysica Acta (BBA)_General Subjects, vol. 1790, no. 11, pp. 1486-1500, 2009.

[29] L. Flohé, S. Toppo, G. Cozza, and F. Ursini, “A comparison of thiol peroxidase mechanisms," Antioxidants and Redox Signaling, vol. 15, no. 3, pp. 763-780, 2011.

[30] S. Katayama, S.-i. Ishikawa, M. Z. Fan, and Y. Mine, "Oligophosphopeptides derived from egg yolk phosvitin upregulate $\gamma$-glutamylcysteine synthetase and antioxidant enzymes against oxidative stress in caco-2 cells," Journal of Agricultural and Food Chemistry, vol. 55, no. 8, pp. 28292835, 2007.

[31] R. Masella, R. Varì, M. D’Archivio et al., "Extra virgin olive oil biophenols inhibit cell-mediated oxidation of LDL by increasing the mRNA transcription of glutathione-related enzymes," The Journal of Nutrition, vol. 134, no. 4, pp. 785-791, 2004.

[32] S. Kameoka, P. Leavitt, C. Chang, and S.-M. Kuo, "Expression of antioxidant proteins in human intestinal Caco-2 cells treated with dietary flavonoids," Cancer Letters, vol. 146, no. 2, pp. 161-167, 1999.

[33] M. F. Knapen, P. L. Zusterzeel, W. H. Peters, and E. A. Steegers, "Glutathione and glutathione-related enzymes in reproduction," European Journal of Obstetrics \& Gynecology and Reproductive Biology, vol. 82, no. 2, pp. 171-184, 1999.

[34] E. R. Stadtman and R. L. Levine, "Free radical-mediated oxidation of free amino acids and amino acid residues in proteins," Amino Acids, vol. 25, no. 3-4, pp. 207-218, 2003.

[35] Y. Guo, T. Zhang, B. Jiang, M. Miao, and W. Mu, "The effects of an antioxidative pentapeptide derived from chickpea protein hydrolysates on oxidative stress in Caco-2 and HT-29 cell lines," Journal of Functional Foods, vol. 7, pp. 719-726, 2014. 